\title{
The Influence of Instructional Delivery Modality on Sustainability Literacy
}

\author{
Simon Ling ${ }^{1, *}$, Adam Landon ${ }^{2}$, Michael Tarrant ${ }^{1}$ and Donald Rubin ${ }^{3}$ \\ 1 Warnell School of Forestry and Natural Resources, University of Georgia, Athens, GA 30602, USA; \\ tarrant@uga.edu \\ 2 Department of Fisheries, Wildlife, and Conservation Biology, University of Minnesota, \\ Saint Paul, MN 55108, USA; aclandon@gmail.com \\ 3 Franklin College of Arts and Sciences, University of Georgia, Athens, GA 30602, USA; drubin@uga.edu \\ * Correspondence: sts.ling@bigpond.com
}

Citation: Ling, S.; Landon, A.; Tarrant, M.; Rubin, D. The Influence of Instructional Delivery Modality on Sustainability Literacy. Sustainability 2021, 13, 10274. https://doi.org/ $10.3390 /$ su131810274

Academic Editor: Brack W. Hale

Received: 23 August 2021

Accepted: 8 September 2021

Published: 14 September 2021

Publisher's Note: MDPI stays neutral with regard to jurisdictional claims in published maps and institutional affiliations.

Copyright: (c) 2021 by the authors. Licensee MDPI, Basel, Switzerland. This article is an open access article distributed under the terms and conditions of the Creative Commons Attribution (CC BY) license (https:// creativecommons.org/licenses/by/ $4.0 /)$.

\begin{abstract}
As human environmental impacts have increased, so has the desirability of sustainable practices in multiple dimensions and at multiple scales. In this context, sustainability literacy has become a desirable outcome of higher education, driving the advance of sustainability as a core component of higher education institutions' missions at local, regional, and global scales. However, little is known about the efficacy of different instructional delivery modalities of higher education courses in delivering desired outcomes of sustainability education. This study employed a quasi-experimental design to explore the relative influence of a limited range of instructional delivery modalities and sustainability content (study abroad/home campus and sustainability/nonsustainability) on growth of sustainability literacy among university students. Within each modality (study abroad or home campus), studying sustainability was associated with higher sustainability literacy scores than studying non-sustainability. However, studying non-sustainability courses abroad showed comparable growth in students' sustainability literacy scores compared to studying sustainability on home campuses. These results support not only the idea that sustainability can be taught but also that study abroad, regardless of course content, may be at least as effective at increasing sustainability literacy as home campus sustainability-related courses.
\end{abstract}

Keywords: sustainability literacy; study abroad; quasi-experimental; sustainability education; higher education

\section{Introduction}

The social, economic, and environmental challenges facing humanity are global in scope [1,2]. Climate change, biodiversity loss, and water scarcity threaten the sustainability of both human and natural systems [3]. Rising to meet these challenges as a society requires a populace informed of the global consequences of their consumer choices, as well as the role that they play within the broader system of social and economic production $[4,5]$.

Education, of course, plays a critical role in modifying consumer behaviors and, with the acquisition of sustainability literacy, individuals may be better equipped to engage in environmental citizenship. While sustainability literacy and knowledge do not necessarily have a direct influence on behavior, they may augment attitudes and behavioral intentions towards related issues. Hungerford and Volk [6] suggested that (pro-)environmental citizenship behaviors are a function of intent, personal empowerment variables (including in-depth knowledge of issues and personal investment), and more distal dimensions of ecological knowledge, values, and worldviews. Thus, if actors remain uninformed about the tenets of sustainability, they will likely struggle to achieve it, even if they possess altruistic values and positive attitudes toward sustainability. Scholars have termed this paradox as the value-action gap [7]. 
Sustainability education has a role to play in closing the value-action gap by providing students with the in-depth knowledge needed to act constructively on positive attitudes and intent toward issues of social, environmental, and economic concern [7-9]. This raises the possibility that sustainability literacy may act as a moderator in the attitude-behavior relationship [10]. Sustainability education is global in nature because environmental problems and solutions are often unrestricted by national boundaries. Thus, there is an inherent connection between global citizenship and sustainability education, i.e., the greater literacy an individual possesses with respect to sustainability, the more likely they are to possess attributes characteristic of the prototypical "global citizen". A global citizen is someone for whom the issues of justice, environment, and civic obligations are key determinants of citizenship [11]. The environmental consciousness and dedication to social justice that are found in sustainability echo these criteria for global citizenship.

The definition of sustainability literacy remains nebulous, perhaps because of the breadth of the term 'sustainability'. Stibbe and Luna's [12] broad approach regards a sustainability literate person as possessing the 'skills, attitudes, competences, dispositions, and values' required to implement a sustainable world. Parkin et al.'s [13] narrower view characterizes sustainability literacy as the 'knowledge, skills and understanding required to fashion a more sustainable future'.

Two core elements emerge from the various definitions. Firstly, sustainability literate individuals possess the knowledge and understanding to differentiate sustainable practices from the unsustainable. Secondly, they also have the skills and competencies required to implement sustainable practices $[13,14]$. Individuals who are literate in sustainability should be able to negotiate life in a manner that reduces the unsustainable impacts their decisions may have on human and non-human others in the present, in the future, and at multiple scales.

Sustainability has emerged as an important component of liberal education $[15,16]$. The university setting is a natural context for students to be exposed to, and gain competence in, sustainability-related concepts through experience and education $[17,18]$. However, little is known of the influence of different modes of instruction, or different pedagogies, on students' sustainability literacy. Using a quasi-experimental design, this study tested the influence of sustainability-focused university curricula, study abroad programs, and the combination thereof on growth in students' sustainability literacy.

\subsection{Sustainability and Sustainability Literacy}

Sustainability is defined broadly as an idealized state of human-environment interaction where the needs of present and future societies are met without eroding the natural capital that supports them, and basic human rights reman attainable by all $[19,20]$. This definition encompasses social, economic, and environmental dimensions: the so called "three-legged stool" or "triple bottom line" [21,22]. Realizing the transition to a sustainable society requires citizens who are able to critically evaluate consumer, political, and developmental decisions in a variety of contexts with respect to impacts on these three domains and the interrelationships among them [19]. More recently, a fourth component, ethics/social justice, has led to the quadruple bottom line conceptualization of sustainability [23].

Sustainability literacy can be defined as 'competence in and knowledge of sustainability concepts' [24]. Therefore, when attempting to measure sustainability literacy care should be taken to ensure that measures do not include assessment of values, attitudes and behaviors, which may be related, but should be considered independently [24]. Coyle [25] argues that 'literacy' should be 'distinct from simple awareness . . because of its depth of information'. Due to the integrative nature of sustainability as a concept, assessing literacy according to these criteria is not a simple task. Measures of sustainability literacy must assess sustainability knowledge, interrelationships of sustainability domains, and the depth of information integration. As such, sustainability literacy measures can be complex, lengthy and face difficulty assessing skills and competence through simple formats such as multiple choice. On the other hand, a primary criticism levelled at many existing instru- 
ments has been the lack of equal assessment of all dimensions in the triple bottom line and the interrelationships among them [24]. Balancing these factors is a significant challenge.

One of the most comprehensive instruments for the assessment of sustainability literacy is the ASK (Assessment of Sustainability Knowledge) [26]. The final version of the ASK retained the sixteen most discriminating questions but has received criticism for lacking questions that integrate all three elements of the triple bottom line [24]. Researchers at the University of North Carolina (UNC) also developed an instrument for the assessment of sustainability literacy. Shorter than the ASK, with thirteen questions focused on sustainability literacy, it incorporates questions requiring integration of knowledge from social, environmental, and economic domains at some depth [27]. However, the psychometric properties of the UNC measure have not been reported.

\subsection{Course Content}

Although many authorities suggest that sustainability literacy can be inculcated via direct instruction (see [28-32]), few studies have tested that supposition quasi-experimentally. College major has a mixed relationship with sustainability literacy [26]. For example, Horvath and colleagues [33] found the number of sustainability related courses a student reported completing had a non-linear relationship with sustainability literacy (using a measure of their own making). These authors reported a threshold effect; students who completed one to two sustainability related courses were not significantly more knowledgeable than those who completed no sustainability courses, while students who completed three or more sustainability related courses were more knowledgeable than students in either of the other categories.

Fisher and McAdams [34] looked at the influence of sustainability coursework type and number of sustainability courses on how students conceptualized sustainability along four indices: ecosystems and nature, eco-efficiency, community and well-being, and systemic change and innovation. They found course content, rather than the number of sustainability courses, influenced the way students conceptualized sustainability within these indices. For example, taking natural science subjects was related to higher scores on the ecosystems and nature index. However, it should be noted that this study examined the relative importance of students assigned to aspects of sustainability rather than sustainability literacy per se.

\subsection{Instructional Delivery Modality}

Few studies have examined the influence of the setting of instructional delivery on sustainability literacy. Most studies examining the relationship of course content, or number of courses, to sustainability literacy have focused on home-campus courses. Limited literature exists examining the impact of study abroad on sustainability literacy compared to homecampus courses. However, there is evidence that participation in international education may positively influence students' understanding of the interconnections between social, economic, and ecological systems; topics germane to sustainability education [35-39]. For example, the interdisciplinary concept of global citizenship as a demonstrated outcome of study abroad programs has generally focused on studies of society and the environment [40-44]. Reysen and Katzarska-Miller [45] define global citizenship as 'awareness, caring, and embracing cultural diversity while promoting social justice and sustainability, coupled with a sense of responsibility to act'. Sustainability is thus regarded as a subset of global citizenship and the relationship between the two depends on the context of all other subsets.

Educational travel abroad where home institution faculty guide students through learning experiences in the field, as opposed to studying abroad in traditional classroom settings, is regarded as having a strong potential to deliver transformational learning experiences for students [46,47], as is experiential learning in and of itself [48]. This may be an influential approach in situations where sustainability education challenges a student to significantly alter their conceptualization of the balance between social, environmental, 
and economic facets of life. Bell et al. [47] looked at 150 US university students that had completed highly experiential programs in the South Pacific. Using qualitative analysis of reflective responses to open-ended questions, they identified four themes associated with sustainability and transformative learning:

1. A new socio-cultural understanding,

2. A new connection with the natural world,

3. Economic considerations,

4. Making changes.

The first three themes resonate strongly with the tenets of sustainability and the triplebottom line, while the fourth is arguably a function of the recognition of the response social justice/ethics demands once understanding of the first three themes is acquired. The 2014-2016 iterations of these programs were sampled as part of this study.

Several studies have found an association between participation in study abroad and learning outcomes related to sustainability literacy, such as sustainability education in tourism [41,43], ethics [49], and global citizenship [50,51]. However, quantitative research solely focused on sustainability literacy and its relationship to instructional delivery modality (e.g., on campus versus off campus) is scarce, despite many universities having offered formal certification in sustainability for some time. More explicit research on outcomes in these programs, may lead to targeted interventions that significantly improve educational goal achievement.

\subsection{Purpose and Hypotheses}

There has been little experimental exploration of the relationships between sustainability content and sustainability literacy in the literature to date. With this gap in mind, our purpose in conducting this study was to test the influence of content (sustainability) and delivery mode (study abroad) commonly employed in university settings to convey sustainability concepts using a quasi-experimental, pre-test/post-test design across one semester of study. Specifically, we hypothesize that:

1. Students engaged in study abroad programs in non-sustainability-focused courses will show greater growth in sustainability literacy than students completing nonsustainability courses on home campus.

2. Students engaged in studying sustainability-focused courses on a home campus will show greater growth in sustainability literacy than students engaged in nonsustainability-focused courses, whether through study abroad or on a home campus.

3. Students engaged in educational travel in sustainability-focused courses will show greater growth in sustainability literacy than students studying in all other courses combined (home campus sustainability, home campus non-sustainability, and study abroad non-sustainability courses).

\section{Materials and Methods}

\subsection{Data Collection}

The study took place at a large public university in the southeastern United States. All instructors of non-online summer courses were invited to participate in the study and courses whose instructors responded positively were included in the study. With Human Subjects approval from the University's Institutional Review Board, surveys were administered to students enrolled in Sustainability Educational Travel courses (SETss; $n=769$ ), Sustainability Home Campus courses (SHC; $n=175)$, Non-Sustainability Study Abroad courses (NSSA; $n=236$ ), and Non-Sustainability-Focused Home Campus courses (NSHC; $n=523$ ) settings during the summer terms of 2014, 2015, and 2016. Surveys were administered in a pretest/posttest design commencing on the first and last day of the class, at least four weeks apart. Participants provided informed consent and generated a unique identifier used to anonymously match pretest and posttest instruments. 


\subsection{Sample Demographics}

Over two-thirds (68.4\%) of participants identified as female. This gender proportion aligns with university-wide enrollment of over $60 \%$ female and also reflects higher proportions of female undergraduate students in the U.S. undertaking short-term study abroad programs [52]. Participants varied in class standing with $10.9 \%$ first year students, $28.2 \%$ sophomores, $35.3 \%$ juniors, $23.2 \%$ seniors, and $2.4 \%$ graduate students.

\subsection{Sustainability Courses}

Courses considered "sustainability-focused" were those listed on the university Office of Sustainability website as applicable to a certificate in sustainability (26 courses over the period 2014-2016). Sustainability courses included topics in ecology, public health, sustainable development, and marine sciences among others, conducted both on campus, in traditional classroom study abroad settings, and field-based educational travel study abroad settings. Non-sustainability courses were courses not listed on the Office of Sustainability website and included topics in sociology, law, language, and history; again, including both on campus and study abroad courses (24 courses over the sampling period).

\subsection{Sustainability Educational Travel}

The educational travel study abroad programs surveyed included at least three credit hours of Field Studies in Natural Resources and were all delivered using a module-based, experiential educational travel pedagogy that moves students through multiple locations exploring relationships between societies and the environment. Students changed locations every three days, on average. Home campus faculty accompanied students, but most of the instruction in the field was delivered by local educators including field guides, public figures, and university faculty. Each location had a learning module associated with it and learning outcomes were assessed by means of quizzes, short answer tests, group presentations, role-playing exercises, and reflective activities.

\subsection{Sustainability Home Campus}

These courses were listed on the Office of Sustainability website but were all delivered in formal classroom settings and included ethics, international relations, humans, nature and environmental awareness, and anthropology. Topics were explored using a range of teaching methods including slideshow presentations, group discussions, and research activities. Assessments included quizzes, assignments, and examinations.

\subsection{Non-Sustainability Study Abroad}

Non-Sustainability Study Abroad courses included international business, Italian art/ceramics, Spanish language and culture, Parisian culture and identity, Scottish culture, education, global food and trade, classics in Rome, critical writing and reviewing, developmental disabilities in Ireland, and South African studies. Most of the instruction occurred in classroom settings, but courses also included some field excursions to explore the culture and landscapes of destination countries. One of the courses housed students in home-stay settings, while the remainder used college-dormitory style accommodations. Teaching assessments included quizzes, group discussions, assignments and examinations.

\subsection{Non-Sustainability Home Campus}

Non-Sustainability Home Campus courses included subjects in psychology, global security, public speaking, technology in mathematics, comparative politics, housing in contemporary society, Spanish texts in global contexts, small group communication, American government, sociology, principles of management, interpersonal communication, dance appreciation, gender and work, criminology, news writing and reporting, religious thought, life-span development, human nutrition, the United States presidency, employment law, intermediate Latin, and terrorism. Topics were explored using a range of teaching methods 
including slideshow presentations, group discussions, and research activities. Assessments included quizzes, assignments, and examinations.

\subsection{Measures}

The measure of sustainability literacy was a knowledge test. Items were drawn from sustainability literacy scales previously administered at the University of North Carolina at Chapel Hill [27] and Ohio State University [26]. Three questions in each of the three dimensions of sustainability (environmental, economic, and social) were selected from these two previous studies for inclusion in the sustainability literacy scale, for the purpose of this study. The questions were selected to reflect sustainability concepts that inform individual choices about human-environment interactions, and to include questions requiring synthesis of knowledge, concepts, and processes. Questions were presented in a multiple-choice format, for which there were five answer choices, including "Don't Know." Each item had a single correct answer. The score on this test was the number of correct answers selected, giving a range of scores from 0-9. Surveys were administered on the first day of classes and then again on the last day of classes. The interval between surveys varied between courses but were at least four weeks apart. The full survey instrument is presented in Appendix A.

\subsection{Sustainability Literacy Scale Validation}

The psychometric properties of the proposed sustainability literacy scale were explored using confirmatory factor analysis. Measurement models were tested in the lavaan package [53] for the R statistical software v3.3.1 [54]. We hypothesized that the sustainability literacy scale measures a single latent construct reflected by the nine items described earlier (Appendix A). Since the data are dichotomous (correct or incorrect), and therefore do not conform to the normality assumptions of maximum likelihood, we used the diagonally weighted least squares (DWLS) estimator with the asymptotic covariance matrix to estimate model parameters. Acceptable model fit was assessed following the recommendations of $\mathrm{Hu}$ and Bentler [55] (Root Mean Square Error of Approximation RMSEA < 0.08; NonNormed Fit Index NNFI, and Comparative Fit Index CFI > 0.95). Convergent validity [56] was assessed via Composite Reliability $(\geq 0.7)$ and the Average Variance Explained $(\geq 0.5)$, at cutoffs recommended by Fornell and Larker [57], and Rykov [58]. Measurement models were tested independently at both pretest and posttest.

\subsection{Hypothesis Testing}

Hypotheses were tested using a factorial repeated measures analysis of variance (ANOVA). Participants were nested in combinations of context (home campus versus abroad) and subject matter (+/-sustainability) and crossed with the repeated measure, time of testing (pretest versus posttest). ANOVA models were estimated using the statistical software SPSS version 25.0 [59]. Planned Helmert contrasts were implemented to test a priori hypotheses. Post-hoc Bonferroni pairwise comparisons were carried out to further explore results.

\section{Results}

\subsection{Scale Validation: Construct Validity, Model Fit, and Reliability}

An initial test of the measurement model (at pretest) demonstrated an adequate fit for the data. However, upon inspection of item factor loadings and modification indices, the item SL2 (Appendix A) failed to load adequately $(\lambda \leq 0.3)$ on the factor and was subsequently dropped from the analysis [57].

Results indicated that the hypothesized scale was valid and reliable when measured at both pretest $\left(\chi^{2}=48.03, \mathrm{df}=20, p=0.03\right.$; $\left.\mathrm{RMSEA}=0.03 ; \mathrm{CFI}=0.98 ; \mathrm{NNFI}=0.97\right)$ and posttest $\left(\chi^{2}=42.34, \mathrm{df}=20, p=0.03\right.$; RMSEA $=0.03 ; \mathrm{CFI}=0.99$; NNFI $\left.=0.99\right)$. The eight-item sustainability literacy scale demonstrated acceptable reliability (Composite Reliability $=0.87$ pre $/ 0.91$ post) [58]. However, the average variance explained by the latent 
factor was slightly lower than is recommended, with values of 0.33 and 0.39 at pretest and posttest respectively. A complete summary of model fit can be found in Table 1.

Table 1. Summary of Model Fit and Reliability for Sustainability Literacy Scale.

\begin{tabular}{ccccccccc}
\hline Model & $\boldsymbol{\chi}^{\mathbf{2}}$ & $\mathbf{d f}$ & $\boldsymbol{p}$-Value & C.R. & AVE & RMSEA & CFI & NNFI \\
\hline Pretest & 48.03 & 20 & 0.03 & 0.87 & 0.33 & 0.03 & 0.98 & 0.97 \\
Posttest & 42.34 & 20 & 0.03 & 0.91 & 0.39 & 0.03 & 0.99 & 0.99 \\
\hline
\end{tabular}

C.R. = Composite Reliability; AVE = Average Variance Explained; RMSEA = Root Square Mean Error of Approximation; CFI = Comparative Fit Index; NNFI = Non-Normed Fit Index; $\mathrm{df}=$ Degrees of Freedom .

\subsection{ANOVA Models}

Cell means for sustainability literacy by Time (pre-test, and post-test) and Context (Sustainability Educational Travel, Sustainability Home Campus, Non-Sustainability Study Abroad, and Non-Sustainability Home Campus) are presented in Table 2. Results of the ANOVA model reveal a significant within-subjects effect for Time x Context $(\mathrm{F}=9.162$, $\mathrm{df}=3, p<0.01)$, but with a small effect size $\left(\eta^{2}=0.016\right)$.

Table 2. Mean and Standard Deviation for Sustainability Literacy at Pretest and Posttest.

\begin{tabular}{cccccc}
\hline Condition & Pretest $\boldsymbol{M}$ & S.D. & Posttest $\boldsymbol{M}$ & S.D. & N \\
\hline $\begin{array}{c}\text { Educational Travel } \\
\text { Sustainability }\end{array}$ & 7.02 & 1.40 & 7.56 & 1.26 & 769 \\
$\begin{array}{c}\text { Home Campus } \\
\text { Sustainability }\end{array}$ & 6.25 & 1.94 & 6.50 & 1.99 & 175 \\
\hline $\begin{array}{c}\text { Study Abroad } \\
\text { Non-Sustainability } \\
\begin{array}{c}\text { Home Campus } \\
\text { Non-Sustainability }\end{array}\end{array}$ & 6.13 & 1.76 & 6.23 & 1.92 & 236 \\
\hline
\end{tabular}

Planned contrasts show no significant difference for gain in sustainability literacy score between NSSA and NSHC (Difference estimate $=0.17$, S.E. $=0.12, p>0.05$ ), and we find no support for $\mathrm{H} 1$ on that basis. Students engaged in study abroad programs in non-sustainability-focused courses did not show greater growth in sustainability literacy than students completing non-sustainability courses on a home campus.

SHC students showed significantly greater gains in sustainability literacy score compared to NSSA and NSHC students combined (Difference estimate $=0.28$, S.E. $=0.13$, $p<0.05)$, supporting H2. Students engaged in studying sustainability-focused courses on a home campus showed greater growth in sustainability literacy than students engaged in non-sustainability-focused courses, whether through study abroad or on a home campus.

SETss students showed significantly greater gains in sustainability literacy score compared to SHC, NSSA, and NSHC students combined (Difference Estimate = 1.1, S.E. = 0.08, $p<0.001$ ), supporting H3. Students engaged in educational travel in sustainability-focused courses showed greater growth in sustainability literacy than students studying in all other courses combined (home campus sustainability, home campus non-sustainability, and study abroad non-sustainability courses).

These results support the hypotheses that participation in sustainability-focused coursework will yield greater growth in sustainability literacy than participation in nonsustainability coursework, and that participation in educational travel focused on sustainability will yield greater growth in sustainability literacy than all other modes of instruction examined in this study (refer to Figure 1).

Bonferroni post-hoc analysis offers greater resolution on the relationship between individual context categories. SETss students show significantly greater gain in sustainability literacy scores than any other category (Table 3). The relationship between SHC, NSSA and 
NSHC is also illuminated. SHC students show significantly greater gain in sustainability literacy score than NSHC students, but not in comparison to NSSA students (Table 3).

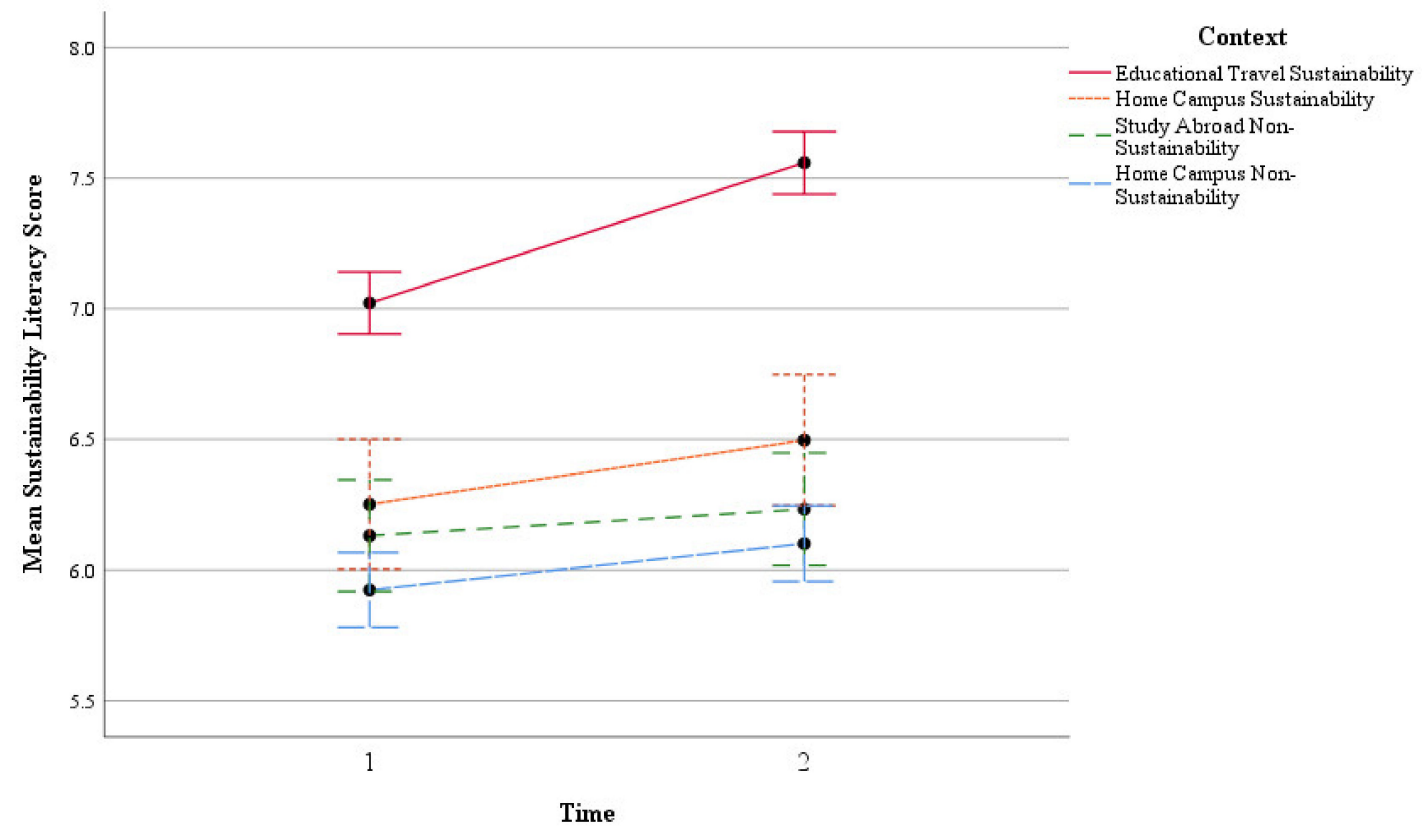

Figure 1. Mean Sustainability Literacy Scores at Pretest and Posttest by Context (error bars represent 95\% C.I.).

Table 3. Pairwise Comparisons for Differences in Mean Sustainability Literacy Score Gain.

\begin{tabular}{ccccc}
\hline & SETss & SHC & NSSA & NSHC \\
\hline SETsS & 0 & $0.92^{*}$ & $1.11^{*}$ & $1.28^{*}$ \\
\hline SHC & $-0.92^{*}$ & 0 & 0.19 & $0.36^{*}$ \\
\hline NSSA & $-1.11^{*}$ & -0.19 & 0 & 0.17 \\
\hline NSHC & $-1.28^{*}$ & $-0.36^{*}$ & -0.17 & 0 \\
\hline
\end{tabular}

Note: differences $=$ Column-Row; ${ }^{*} p<0.05$ after Bonferroni adjustment; SETss $=$ Sustainability Educational Travel sensu stricto; $\mathrm{SHC}=$ Sustainability Home Campus; NSSA = Non-sustainability Study Abroad; NSHC = Nonsustainability Home Campus.

\section{Discussion}

This study supports the idea that sustainability literacy can be learned through direct sustainability instruction (as per [28-32]). This builds on the work of Fisher and McAdams' [34] by extending the investigation of what influences sustainability literacy into direct sustainability literacy assessment, rather than student perspective on the relative importance of various aspects of sustainability. Furthermore, this study also found that differences in sustainability literacy exist between modes of instructional delivery.

Our results demonstrate that educational travel focused on sustainability is an effective means of promoting growth in students' sustainability literacy over and above non-study abroad sustainability and non-sustainability education. Students studying abroad in the field on mobile, experiential programs and undertaking coursework recognized as contributing to campus sustainability initiatives (SETss) demonstrated significantly greater growth in sustainability literacy compared to contemporaries engaged in more traditional study settings. These results reflect the growth potential in a single term of studying sustainability abroad and are, thus, a lower bound estimate in assessing the efficacy of potential sustainability education efforts on campus. It remains to be seen what longer exposure to sustainability focused educational travel may yield.

The Bruntland Report [19] visualizes sustainable societies consisting of citizens able to critically evaluate sustainability issues in a variety of contexts while negotiating a balance 
between consumer, political and developmental outcomes. From this perspective, it is possible that the increased sustainability literacy gains exhibited by SETss students is related to their exposure to a multitude of approaches to sustainability. This is a consequence of the programs' high degree of mobility, which sees students and faculty switch locations to examine a different take on the three-legged stool every three to four days. Of course, this may simply be one influential factor among many.

The variety of instructional settings associated with SETss may also contribute from a 'something for everyone' perspective. This perspective is rooted in the concept of 'Learning Styles', which has had a somewhat chequered past in the literature (see $[60,61]$ ). Pashler et al. [61] found little support for the deployment of learning styles as a basis for 'deciding what kind of instruction to offer each individual' while conceding that 'one student may achieve enlightenment from an approach that seems useless for another student'. Regardless, Learning Styles remains an active area of contemporary education research, particularly in adaptive online learning (see [62,63]).

SETss programs deliver content and engage students using a combination of formal classroom settings (low density), group learning (moderate density), reflection (moderate density), and learning in the field (high density) delivered by both home-campus and in-country faculty on island study abroad programs. It is possible that the broad range of teaching approaches and learning settings allows students to match their most effective mode of learning with modes of instructional delivery at least some of the time, thus increasing the acquisition of sustainability literacy. Furthermore, the novel experiences delivered by study abroad may help solidify student learning by being associated with the memory of those physical, intellectual, and social experiences.

The link between educational travel and support for environmental policies has already been established $[36,64]$. The acquisition of sustainability knowledge through experiential learning on study abroad programs has also been investigated, at least to some degree [47]. While post-program evaluations of experiential learning programs report qualitative themes of sustainability, scales such as the one employed here allow us to acquire quantitative evidence for increases in sustainability fluency related to so-called transformational programs. Sustainability literacy can, and should, be measured if we deem it to be an important part of tertiary education outcomes.

In addition, it is of interest whether particular aspects of the educational travel model contribute more to gains in sustainability literacy than others. If one learning setting is responsible for greater gains in sustainability literacy more than others, is it transferable to traditional classroom settings and if so, does it demonstrate a similar effect in that setting? Testing this quasi-experimentally should be possible.

This research suggests studying abroad in the absence of sustainability-focused pedagogy may provide similar benefits in terms of gains in sustainability literacy as studying sustainability on home campus, although the differences are relatively small. It is plausible that this may be the results of exposure to differing worldviews, to relationships formed within and with other cultures, or to the experience of negotiating the complexities of unfamiliar societies.

\section{Limitations}

Although we feel that the results are promising, several limitations should be noted. First, the sustainability literacy scale was comprised of a relatively low number of items. This was a deliberate action to aid in the administration of the instrument (and correspondingly in the efficiency of assessment delivery). A larger item scale may enable better discrimination of scores and may improve the overall ability of the scale to judge sustainability literacy. However, a tradeoff exists in item number and cognitive burden in survey administration. Second, we sampled only one type of sustainability study abroad program. Results from similar research on other sustainability study abroad approaches may differ from those presented here. Third, our sample consisted of undergraduate students at a southeastern university that may not be representative of the university population at large. 
Certainly, for study abroad programs, self-selection is always a concern with regards to randomization.

The observation that SETss students started programs with sustainability literacy scores above other groups, and demonstrated greater gains, may be evidence for selfselected SETss students being pre-disposed to the subject matter of the course and thus more influenced by it. However, self-selection should therefore also be a concern with homecampus sustainability students whose sustainability literacy gains were not as great as those of SETss students. This gives the authors some confidence that the gains in sustainability literacy exhibited by SETss students cannot solely be explained by self-selection.

Fourth, there is wide variability in the amount of sustainability-related material taught in the courses involved in this study. Quantification of the degree of program fidelity, and of the types and ratios of teaching/learning occurring in each course (e.g., experiential versus reflective), would increase the resolution of conclusions. Finally, and intimately related to the previous point, instructor bias is a confounding variable whose effects are unknown.

\section{Conclusions}

As the world's population has increased, and competition for scarce resources has become more salient, sustainability has moved to the forefront of international and domestic discourse. It is now incumbent on higher education institutions to prepare graduates that can follow, understand, and meaningfully participate in discourses such as the UN's 'Transforming our world: the 2030 Agenda for Sustainable Development' [65]. Many are making significant moves in that direction in curricula. as well as on-campus policies.

In quasi-experimentally assessing students' functional knowledge of the Triple Bottom Line, this study provides important context for the types of instructional settings able to optimize or promote sustainability literacy as a specific learning outcome. For example, if gains in sustainability literacy are regarded as a desirable additional outcome of a given tertiary institutions' facilitation and promotion of study abroad programs, this work suggests that not all study abroad approaches are created equally in that regard.

The current global pandemic has presented both challenges and opportunities to college study abroad educators. For example, the SETss programs sampled here have not run since in 2020 and 2021, and there are currently no guarantees that 2022 will see this change. The opportunity arising from current constraints is the chance to simulate, or replicate, the approach utilized by SETss programs in the design of home-campus sustainability courses, and test their relationship to sustainability literacy in a similar fashion.

While such a transposition may appear challenging, technologically there has never been a better time to look at trialing online experiences as a proxy for study abroad programs that cannot run. Will they prove a poor cousin? It's a question worth answering.

Author Contributions: Conceptualization, M.T. and S.L.; methodology, M.T.; validation, S.L. and A.L.; formal analysis, S.L., A.L.; investigation, S.L.; data curation, S.L. and A.L.; writing-original draft preparation, S.L.; writing-review and editing, S.L., A.L., M.T. and D.R. All authors have read and agreed to the published version of the manuscript.

Funding: This research received no external funding.

Institutional Review Board Statement: The study was conducted according to the guidelines of the Declaration of Helsinki, and approved by the Institutional Review Board (or Ethics Committee) of the University of Georgia.

Informed Consent Statement: Informed consent was obtained from all subjects involved in the study.

Conflicts of Interest: The authors declare no conflict of interest.

\section{Appendix A}

Survey instrument-Correct answers in bold, origin of question in parentheses $(\mathrm{OSU}=$ Ohio State University, UNC = University of North Carolina $)$. 


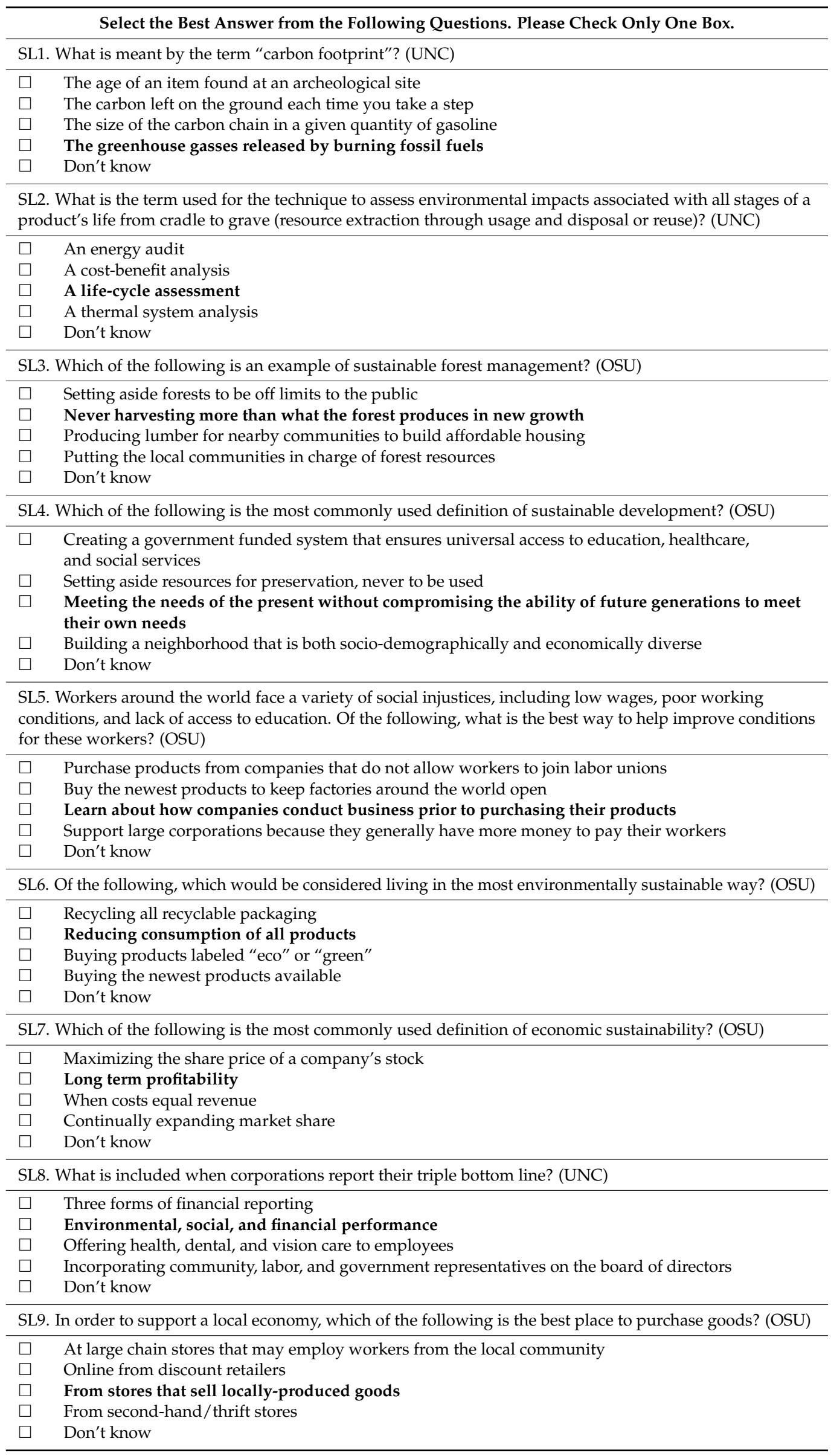




\section{References}

1. Steffen, W.; Crutzen, P.J.; McNeill, J.R. The anthropocene: Are humans now overwhelming the great forces of nature? Ambio 2007, 36, 614-621. [CrossRef]

2. Röckstrom, J.; Steffen, W.; Noone, K.; Persson, A.; Chapin, F.S., III; Lambin, E.; Lenton, T.M.; Scheffer, M.; Folke Schellenhuber, H.J.; Nkvist, B.; et al. Planetary boundaries: Exploring the safe operating space for humanity. Ecol. Soc. 2009, 14, 32. [CrossRef]

3. Millennium Ecosystem Assessment (MEA). Ecosystems and Human Well-Being: Synthesis; Island Press: Washington, DC, USA, 2005.

4. Nassauer, J.I. Care and stewardship: From home to planet. Landsc. Urban Plan. 2011, 100, 321-323. [CrossRef]

5. Schultz, P.W. Conservation means behavior. Conserv. Biol. 2011, 25, 1080-1083. [CrossRef] [PubMed]

6. Hungerford, H.R.; Volk, T.L. Changing learner behavior through environmental education. J. Environ. Educ. 1990, $21,8-21$. [CrossRef]

7. Kollmus, A.; Agyeman, J. Mind the gap: Why do people act environmentally and what are the barriers to pro-environmental behavior. Environ. Educ. Res. 2002, 8, 239-260. [CrossRef]

8. Chaplin, G.; Wyton, P. Student engagement with sustainability: Understanding the value-action gap. Int. J. Sustain. High. Educ. 2014, 15, 404-417. [CrossRef]

9. Hungerford, H.R.; Peyton, R.B.; Wilke, R.J. Goals for curriculum development in environmental education. J. Environ. Educ. 1980, 11, 42-46. [CrossRef]

10. Fishbein, M.; Ajzen, I. Predicting and Changing Behavior: The Reasoned Action Approach; Psychology Press: New York, NY, USA, 2010.

11. Dobson, A. Citizenship and the Environment; Oxford University Press: Oxford, UK, 2003.

12. Stibbe, A.; Luna, H. Introduction. In The Handbook of Sustainability Literacy: Skills for a Changing World; Green Books Ltd.: Dartington, UK, 2009.

13. Parkin, S.; Johnston, A.; Buckland, H.; Brookes, F.; White, E. Learning and Skills for Sustainable Development: Developing a Sustainability Literate Society—Guidance for Higher Education Institutions; Forum for the Future: London, UK, 2004.

14. Winter, J.; Cotton, D. Making the hidden curriculum visible: Sustainability literacy in higher education. Environ. Educ. Res. 2012, 18, 783-796. [CrossRef]

15. Warburton, K. Deep learning and education for sustainability. Int. J. Sustain. High. Educ. 2003, 4, 44-56. [CrossRef]

16. Cortese, A.D.; Hattan, A.S. Research and solutions: Education for sustainability as the mission of higher education. Sustain. J. Rec. 2010, 3, 48-52. [CrossRef]

17. Bowers, C.A. Challenges in educating for ecologically sustainable communities. Educ. Philos. Theory 2001, 33, 257-265. [CrossRef]

18. Bowers, C.A. Toward an eco-justice pedagogy. Environ. Educ. Res. 2002, 8, 21-34. [CrossRef]

19. World Commission on Environment and Development. Our Common Future. Oxford. 1987. Available online: http://mom.gov. af/Content/files/Bruntland_Report.pdf (accessed on 15 August 2018).

20. Solow, R.M. Sustainability: An Economists Perspective. In Economics of the Environment; Stavins, R.N., Ed.; W.W. Norton and Company: New York, NY, USA, 1991; pp. 131-138.

21. Elkington, J. Towards the sustainable corporation: Win win win business strategies for sustainable development. Calif. Manag. Rev. 1994, 36, 90-100. [CrossRef]

22. Dawe, N.K.; Ryan, K.L. The faulty three-legged-stool model of sustainable development. Conserv. Biol. 2003, 17, 1458-1460. [CrossRef]

23. Inayatullah, S. Spirituality as the fourth bottom line? Futures 2005, 37, 573-579. [CrossRef]

24. Barnes, N. Institutional Attempts to Measure Student Sustainability Knowledge. Sustain. J. Rec. 2014, 7, 104-108. [CrossRef]

25. Coyle, K. Environmental Literacy in America: What Ten Years of Neeft/Roper Research and Related Studies Say about Environmental Literacy in the U.S.; The National Environmental Education and Training Foundation: Washington, DC, USA, $2005 ;$ pp. 1-152.

26. Zwickle, A.; Koontz, T.M.; Slagle, K.M.; Bruskotter, J.T. Assessing sustainability knowledge in the environmental, economic, and social domains. Int. J. Sustain. High. Educ. 2014, 15, 375-389. [CrossRef]

27. University of North Carolina. Sustainability Literacy Assessment Report. 2012. Available online: https://sustainability.unc.edu/ files/2015/12/Sustainability-Literacy-Assessment-Report-Nov2012.pdf (accessed on 15 August 2018).

28. Armstrong, C.M. Implementing education for sustainable development: The potential use of time-honored pedagogical practice from the Progressive Era of Education. J. Sustain. Educ. 2011, 2, 221-236.

29. Burns, H. Meaningful sustainability learning: A study of sustainability pedagogy in two university courses. Int. J. Teach. Learn. High. Educ. 2013, 25, 166-175.

30. Burns, H. Transformative sustainability pedagogy: Learning from ecological systems and indigenous wisdom. J. Transform. Educ. 2015, 13, 259-276. [CrossRef]

31. Howlett, C.; Ferreira, J.L.; Blomfield, J.M. Teaching sustainable development in higher education: Building critical, reflective thinkers through an interdisciplinary approach. Int. J. Sustain. High. Educ. 2016, 17, 305-321. [CrossRef]

32. Segalàs, J.; Mulder, K.F.; Ferrer-Balas, D. What do EESD “experts” think sustainability is? Which pedagogy is suitable to learn it?: Results from interviews and Cmaps analysis gathered at EESD 2008. Int. J. Sustain. High. Educ. 2012, 13, 293-304. [CrossRef]

33. Horvath, N.; Steward, M.; Shea, M. Toward instruments of assessing sustainability knowledge: Assessment development, process, and results from a pilot survey at the University of Maryland. J. Sustain. Educ. 2013, 5, 27. 
34. Fisher, P.B.; McAdams, E. Gaps in sustainability education: The impacts of higher education coursework on perceptions of sustainability. Int. J. Sustain. High. Educ. 2015, 16, 407-423. [CrossRef]

35. Myers, D.N.; Hill, M.; Harwood, S.A. Cross-Cultural Learning and Study Abroad: Transforming Pedagogical Outcomes. Landsc. J. 2005, 24, 172-184. [CrossRef]

36. Cusick, J. Study abroad in support of education for sustainability: A New Zealand case study. Environ. Dev. Sustain. 2009, 11, 801-813. [CrossRef]

37. Tarrant, M.A. A Conceptual Framework for Exploring the Role of Studies Abroad in Nurturing Global Citizenship. J. Stud. Int. Educ. 2010, 14, 433-451. [CrossRef]

38. Lee, Y.S.; Schottenfeld, M.A. Internationalising Experiential Learning for Sustainable Development Education. J. Educ. Sustain. Dev. 2012, 6, 341-354. [CrossRef]

39. Reilly, A.H.; McGrath, M.A.; Reilly, K. Beyond 'Innocents Abroad': Reflecting on Sustainability Issues during International Study Trips. J. Technol. Manag. Innov. 2016, 11, 29-37. [CrossRef]

40. Tarrant, M.; Lyons, K. The effect of short-term educational travel programs on environmental citizenship. Environ. Educ. Res. 2012, 18, 403-416. [CrossRef]

41. Tarrant, M.; Rubin, D.; Stoner, L. The effects of studying abroad and studying sustainability on students' global perspectives. Front. Interdiscip. J. Study Abroad 2015, 26, 68-82. [CrossRef]

42. Tarrant, M.A.; Stoner, L.; Tessman, K.; Gleason, M.; Lyons, K.; Wearing, S. Global programs in sustainability: A case study of techniques, tools, and teaching strategies for sustainability education in tourism. In Education for Sustainability in Tourism: A Handbook of Processes, Resources, and Strategies; Moscardo, G., Benckendorff, P., Eds.; Springer: New York, NY, USA, 2015; pp. 229-237.

43. Wearing, S.; Tarrant, M.A.; Schweinsberg, S.; Lyons, K.; Stoner, K. Exploring the Global in Student Assessment and Feedback for Sustainable Tourism Education. In Education for Sustainability in Tourism. CSR, Sustainability, Ethics and Governance; Moscardo, G., Benckendorff, P., Eds.; Springer: Berlin/Heidelberg, Germany, 2015.

44. Landon, A.C.; Tarrant, M.A.; Rubin, D.A.; Stoner, L. Beyond "Just Do It": Fostering higher-order learning outcomes in short-term study abroad. AERA Open 2017,3,1-7. [CrossRef]

45. Reysen, S.; Katzarska-Miller, I. A model of global citizenship: Antecedents and outcomes. Int. J. Psychol. 2013, 48, 858-870. [CrossRef]

46. Ritchie, M.A. Sustainability Education, Experiential Learning, and Social Justice: Designing Community Based Courses in the Global South. J. Sustain. Educ. 2013, 5, 216-227.

47. Bell, H.L.; Gibson, H.J.; Tarrant, M.A.; Perry, L.G.; Stoner, L. Transformational learning through study abroad: US students' reflections on learning about sustainability in the South Pacific. Leis. Stud. 2014, 4367, 389-405. [CrossRef]

48. Owens, C.; Sotoudehnia, M.; Erickson-McGee, P. Reflections on teaching and learning for sustainability from the Cascadia Sustainability Field School. J. Geogr. High. Educ. 2015, 39, 313-327. [CrossRef]

49. Parmentier, M.J.; Moore, S. ‘The Camels are Unsustainable': Using Study Abroad as a Pedagogical Tool for Teaching Ethics and Sustainable Development. Teach. Ethics 2016, 16, 207-221. [CrossRef]

50. Tarrant, M.A.; Lyons, K.; Stoner, L.; Kyle, G.T.; Wearing, S.; Poudyal, N. Global Citizenry, educational travel and sustainable tourism: Evidence from Australia and New Zealand. J. Sustain. Tour. 2014, 22, 403-420. [CrossRef]

51. Tarrant, M.A.; Rubin, D.L.; Stoner, L. The added value of study abroad: Fostering a global citizenry. J. Stud. Int. Educ. 2014, 26, 68-82. [CrossRef]

52. Selingo, J. Why Are So Few Male Students Studying Abroad? Available online: https://www.theatlantic.com/education/ archive/2019/02/male-students-studying-abroad/583828/ (accessed on 22 August 2019).

53. Rossel, Y. lavaan: An R package for structural equation modeling. J. Stat. Softw. 2012, 48, 1-36. [CrossRef]

54. R Development Core Team. R: A Language and Environment for Statistical Computing; R Foundation for Statistical Computing: Vienna, Austria, 2016.

55. Hu, L.; Bentler, P.M. Cutoff criteria for fit indices in covariance structure analysis: Conventional criteria versus new alternatives. Struct. Equ. Model. A Multidiscip. J. 1999, 6, 1-55. [CrossRef]

56. Netemeyer, R.G.; Bearden, W.O.; Sharma, S. Scaling Procedures: Issues and Applications; Sage: Thousand Oaks, CA, USA, 2003.

57. Fornell, C.; Larker, D.F. Evaluating structural equation models with unobservable variables and measurement error. J. Mark. Res. 1981, 18, 39-50. [CrossRef]

58. Rykov, T. Estimation of composite reliability for congeneric measures. Appl. Psychol. Meas. 1997, 21, 173-184. [CrossRef]

59. IBM Corp. IBM SPSS Statistics for Windows; Version 25.0; IBM Corp: Armonk, NY, USA, 2017.

60. Kolb, D.A. Experiential Learning: Experience as the source of learning and development. In Englewood Cliffs; Prentice-Hall: Hoboken, NJ, USA, 1984.

61. Pashler, H.; McDaniel, M.; Rohrer, D.; Bjork, R. Learning Styles: Concepts and Evidence. Psychol. Sci. Public Interest 2008, 9 , 105-119. [CrossRef] [PubMed]

62. Yang, T.-C.; Hwang, G.-J.; Yang, S.J.-H. Development of an adaptive learning system with multiple perspectives based on students' learning styles and cognitive styles. Educ. Technol. Soc. 2013, 16, 185-200.

63. Lu, H.; Jia, L.; Gong, S.H.; Clark, B. The Relationship of Kolb Learning Styles, Online Learning Behaviors and Learning Outcomes. Educ. Technol. Soc. 2007, 10, 187-196. 
64. Tarrant, M.; Stoner, L.; Borrie, W.T.; Kyle, G.; Moore, R.L.; Moore, A. Educational travel and global citizenship. J. Leis. Res. 2011, 43, 403-426. [CrossRef]

65. UN General Assembly. Transforming Our World: The 2030 Agenda for Sustainable Development. 2015. Available online: https://www.un.org/ga/search/view_doc.asp?symbol=A/RES/70/1\&Lang=E (accessed on 21 October 2015). 